\title{
Sejarah Pemikiran Ekonomi Islam dari Zaman Nabi Muhammad SAW sampai Kontemporer
}

\author{
Tenri Femy Farasiah
}

A. Masa Nabi

Kelahiran nabi muhammad menjadi berita gembira bagi umat muslim. Awal mulanya terjadi perkembangan ekonomi Islam terjadi pada masa nabi Muhammad SAW. Sejarah mencatat bahwa, asal mula pemikiran ekonomi Islam telah dilakukan pada masa Rasulullah SAW dan sahabatnya. ${ }^{1}$

Adapun dimasa Rasulullah SAW, beberapa sumber pendapatan yaitu jizya yang merupakan pajak bagi orang non muslim. Kharaj, dipungut dari non muslim sebagai pajak tanah. Ushr, merupakan bea impor yang harus dibayarkan oleh para pedagang.

B. Khalifah

Ada 4 orang sahabat pada masa ini, yaitu Abu Bakar Ash-Shidiq, Umar bin Khattab, Usman bin Affan, Ali bin Abi Thalib.

Dimasa Abu bakar, Abu Bakar telah memenuhi kebutuhan masyarakannya dengan menggunakan harta baitul maal dimanakebijakan ekonomi dimasa Abu Bakar yaitu melakukan penegakan hukum terhadap orang yang tidak ingin membayar pajak.

Dimasa Umar bin Khattab, sitem ekonomi yang diterapkan berdasar pada keadilan dan juga kebersamaan. hal ini lah yang menjadikan masa Umar bin Khattab menjadi masa keemasan dalam sejarah Islam.

Usman bin Affan, tidak ada perubahan yang signifikan selama kepemimpinan beliau, melainkan dengan mempertahankan kepemimpinan sebelumnya.

Ali bin Abi Tholib, dimasa ini banyak memberhentikan pejabat yang korup. Dan membuka kembali lahan yang diberikan kepada orang terdekatusman untuk di kelola kembali.

C. Dinasti

${ }^{1}$ Winarno, Sejarah Pemikiran Ekonomi Islam di Masa Rasulullah SAW, vol 2 no. 1 (2017) 


\section{Bani Umayyah}

Pemerintahan dimasa ini disebut sebagai pemerintahan yang agresif dilihat dari upaya untuk melakukan ekspansi yang pastinya terkait dengan bidang ekonomi. ${ }^{2}$ Bani umayyah juga banyak banyak berjasa dalam pembangunan di berbagai bidang seperti, membangun panti- panti untuk orang cacat, membangun jalan raya yang menghubungkan satu daerah dengan daerah lainnya, pabrik, gedung pemerintah dan masjid.

Khalifa Umar ibn Abd Al-Aziz, dalam kepemimpinannya mengguanakn konsep welfare state, yang artinya negarayang sejahtera. Umar memiliki kebijakan baru untuk merubah taraf hidup dari masyarakat. Sebagai bukti dari kepemimpinannya itu adalah tidak ditemukannya orang yang dapat menerima zakat sebab mereka telah berkecukupan. ${ }^{3}$

Sepeninggalan Umar ibn Abd Al-Aziz, kekuasaan bani umayyah berada dibawah Yazid ibn Abd Al-Malik. Penguasa yang ini, terlalu bermewah mewahan dan tidk mengurus rakyat sehingga ini lah menjadi akhir dari kepemimpinan bani umayyah sebab kacaunya masyarakat karena kepemimpinannya.

2. Abbasiyah

Perkembangan bidang pertanian maju pesat pada awal pemerintahan Dinasty Abbasiyah karena pusat pemerintahannya berada di daerah yang sangat subur. ${ }^{4}$ Lahan pertanian yang terlantar dan di sia siakan diperbaiki kembali dan dibuatkan saluran perairannya sehingga membentuk jaringan yang sempurna.

Dinasti abbasiyah mendapat keberhasilannya sebab bersatunya dalam menyatukan perpecahan yang terjadi sebelumnya.

Stelah berganti priode, di priode kepemimpinan akhir mereka lebih memikirkan urusan pribadi dan tanggung jawab pribadinya dibanding

\footnotetext{
${ }^{2}$ Muhammad Dliyaul Muflihin, Perekonomian di Masa Dinasti Umayyah, vol 3no 1 (2020)

${ }^{3}$ Annisa Silvi Kusumastuti, Mohammad Ghozali, Konsep Welfare State Pada Kebijakan Umar Bin Abdul Aziz Sebagai Khalifah Bani Umayyah, vol.6 no.2 (2019), La Maisyir

${ }^{4}$ Meriyati, Perkembangan Ekonomi Islam pada Masa Dulah Abbasiyah, vol 4 no. 1, (2018)
} 
kewajibannya terhadap negara, hal ini yang menjadi dasar kemunduran dinasti abbasiyah.

D. Marcantilisme

Merupakan kebijakan ekonomiyang diterapkan diwilayah eropa pada abad 16-18. Kebijakan ini menambah kekuasaan negara dengan mengorbankan kekuatan pesaingnya. Kebijakan yang melihat kesejahteraan suatu negara hanya dapat di lihat dari banyaknya aset dan modalyang di simpan negara tersebut.

Setelah kebijakan ini mendominan, ternyata banyak sekali memicu peperangan di kalangan negara eropa. Ini lah yang menjadi penyebab lahirnya kebijakan kapitalis

E. Kapitalisme

Sistem ekonomi kapitalis merupakan sistem ekonomi yang hak milik privat atas alat produksi dan distribusi dan juga pemanfaatannya dalam meraih keuntungan. Kapitalisme ini bersal dari pemikiran Adam Smith. Doktrin yang diajarkan "The Welth of Nation", "Laissez Faire",dan prinsip "the invisible hand" teori adam smith ini mampu bertahan sampai terjadinya depresi ekonomi 1929 namun setelah 30 thun berlalu teori ini kembali tampildengan nama neoliberalisme

F. Soialisme

Bentukperekonomian yang pemerintahannya kurang mengambil tindakan dalam peranya mengendalikan industry besar seperti pertambangan dan industy lainnya. ${ }^{5}$

Dalam masyarakat sosialis yang menonjol adalah kebersamaan dan juga kolektivismenya.

G. Kontemporer

Mannan berhasil mengurai tentang kerangka dan juga ciri khusus ekonomi Islam. Sejalan dengan waktu, ruanglingkup dan pembahasan ekonomi Islam semakin meluas sampai hari ini.

\footnotetext{
${ }^{5}$ Itang, Adib Daenuri, Sistem Ekonomi Kapitalis, Sosial dan Islam, vol 18 no 1, (2017)
} 